\title{
Antispasmodic and vasodilator activities of Morinda citrifolia root extract are mediated through blockade of voltage dependent calcium channels
}

\author{
Anwarul Hassan Gilani ${ }^{1,3 *}$, Saf-ur-Rehman Mandukhail ${ }^{1,2+}$, Javeid lqbal ${ }^{2 \dagger}$, Masoom Yasinzai ${ }^{2 \dagger}$, Nauman Aziz $^{1 \dagger}$, \\ Aslam Khan ${ }^{1 \dagger}$, Najeeb-ur-Rehman ${ }^{1 \dagger}$
}

\begin{abstract}
Background: Morinda citrifolia (Noni) is an edible plant with wide range of medicinal uses. It occurs exclusively in tropical climate zone from India through Southeast Asia and Australia to Eastern Polynesia and Hawaii. The objective of this study was to explore the possible mode(s) of action for its antispasmodic, vasodilator and cardiosuppressant effects to rationalize its medicinal use in gut and cardiovascular disorders.

Methods: Isolated tissue preparations such as, rabbit jejunum, rat and rabbit aorta and guinea pig atria were used to test the antispasmodic and cardiovascular relaxant effects and the possible mode of action(s) of the 70\% aqueous-ethanolic extract of Morinda citrifolia roots (Mc.Cr).

Results: The Mc.Cr produced a concentration-dependent relaxation of spontaneous and high $\mathrm{K}^{+}$induced contractions in isolated rabbit jejunum preparations. It also caused right ward shift in the concentration response curves of $\mathrm{Ca}^{++}$, similar to that of verapamil. In guinea-pig right atria, $\mathrm{Mc}$.Cr caused inhibition of both atrial force and rate of spontaneous contractions. In rabbit thoracic aortic preparations, Mc.Cr also suppressed contractions induced by phenylephrine $(1.0 \mu \mathrm{M})$ in normal- $\mathrm{Ca}^{++}$and $\mathrm{Ca}^{++}$-free Kerb's solutions and by high $\mathrm{K}^{+}$, similar to that of verapamil. In rat thoracic aortic preparations, Mc.Cr also relaxed the phenylephrine $(1.0 \mu \mathrm{M})$-induced contractions. The vasodilatory responses were not altered in the presence of L-NAME $(0.1 \mathrm{mM})$ or atropine $(1.0 \mu \mathrm{M})$ and removal of endothelium.

Conclusions: These results suggest that the spasmolytic and vasodilator effects of Mc.Cr root extract are mediated possibly through blockade of voltage-dependent calcium channels and release of intracellular calcium, which may explain the medicinal use of Morinda citrifolia in diarrhea and hypertension. However, more detailed studies are required to assess the safety and efficacy of this plant.
\end{abstract}

\section{Background}

Morinda citrifolia Linn (Fam. Rubiaceae) is commonly known as Noni or Indian mulberry. It occurs from India through Southeast Asia and Australia to Eastern Polynesia and Hawaii [1]. It is an edible plant and has been used in herbal remedies to treat various common diseases and to maintain overall good health [2]. Different

\footnotetext{
* Correspondence: anwar.gilani@aku.edu

† Contributed equally

${ }^{1}$ Natural Product Research Division, Department of Biological and Biomedical

Sciences, Aga Khan University Medical College, stadium road, Karachi-74800, Pakistan
}

(c) 2010 Gilani et al; licensee BioMed Central Ltd. This is an Open Access article distributed under the terms of the Creative Commons Attribution License (http://creativecommons.org/licenses/by/2.0), which permits unrestricted use, distribution, and reproduction in any medium, provided the original work is properly cited.

parts of the plant including stem, bark, root, leaf, and fruits have been used in the system of traditional medicine to treat a broad range of diseases, including hypertension [3], atherosclerosis [2], colic [4] and diarrhea [5].

Morinda citrifolia, has been reported to possess antithrombotic [6], antioxidant [7], analgesic and antiinflammatory [8] and xanthine oxidase inhibitory [9] activities There are also preliminary studies reporting its blood pressure lowering[10] and vasodilatory [11] properties. However, the possible modes of action(s) of cardiovascular activities are lacking. The current study 
reports possible mode of action(s) of antihypertensive, vasodilator and antispasmodic activities.

\section{Methods}

Plant material

The vacuum dried $70 \%$ aqueous-ethanolic extract of Morinda citrifolia root was obtained from the Sami Labs Limited 19/1, 19/2, 1st Main II Phase, Peenya, Peenya Industrial Area Bangalor-560 058, India. The extract was prepared by following procedure as described by the manufacturer. Dried roots of Morinda citrifolia were procured from a reputed herb supplier in Southern India. The roots were chopped and ground by hammer mill and passed through 20 mesh screen. The powder $(12 \mathrm{Kg})$ was extracted with $70 \%$ ethanol $(48 \mathrm{~L})$ at $70^{\circ} \mathrm{C}$ for 3 hours and filtered. The procedure repeated 2 more times and all filtrates combined and evaporated under vacuum. The dried extract was packed in polythene bags with nitrogen purge. The yield of the extract was $3.75 \%$.

A sample of the extract was deposited at the herbarium of department of biological and biomedical sciences, Aga Khan University Karachi, Pakistan with voucher \# MC-RT-02-08-82.

\section{Phytochemical screening}

The Morinda citrifolia root extract was tested for the presence of various phytochemical classes of compounds such as alkaloids, phenolic compounds, strerols, flavonoids, tannins, coumarins and anthraquinones using method described by Khan and Gilani [12].

\section{Drugs and standards}

The following reference chemicals were obtained from the source specified acetylcholine chloride, atropine sulfate, Nù-nitro-L-arginine methyl ester (L-NAME), phenylephrine hydrochloride, and verapamil hydrochloride (Sigma Chemical Company, ST Louis, MO). The following chemicals were used to make the physiological salts solution: potassium chloride (Sigma Chemicals Co.), calcium chloride, glucose, magnesium chloride, magnesium sulfate, potassium dihydrogen phosphate, sodium bicarbonate, sodium dihydrogen phosphate (Merck, Darmstadt, Germany) and sodium chloride (BDH Laboratory Supplies, Poole, England). All chemicals used were of the analytical grade available and dissolved in distilled water.

\section{Animals}

Rabbits (1000-1300 g), guinea-pigs (500-600 g), SpragueDawley rats (180-220 g) and mice (20-25) of either sex were obtained from the animal house of the Aga Khan University, Karachi. The animals were housed in constant room temperature $\left(23-25^{\circ} \mathrm{C}\right)$ and given free access to food and water. Rabbits and guinea-pigs were starved for $24 \mathrm{hrs}$ prior to experiment and sacrificed by cervical dislocation. Experiments performed complied with the rulings of the Institute of Laboratory Animal Resources, Commission on Life Sciences [13] and approved by the Ethical Committee of the Aga Khan University, Karachi.

\section{Isolated tissue preparations \\ Rabbit jejunum}

The spasmolytic activity and possible mode of action of the plant materials were studied by using isolated rabbit jejunum as described previously [14]. Each segment of about $2 \mathrm{~cm}$ length was suspended in a $10 \mathrm{ml}$ tissue bath containing Tyrode's solution, maintained at $37^{\circ} \mathrm{C}$ and aerated with a mixture of $95 \%$ oxygen and $5 \%$ carbon dioxide (carbogen). The tissues were allowed to equilibrate for at least $30 \mathrm{~min}$ at preload of $1 \mathrm{~g}$. Tension changes in the tissue were recorded via a force displacement transducer (model FT-03) coupled with Bridge Amp and PowerLab 4/25 data acquisition system connected to computer running chart 5.3 software (ADInstrument, Sydney, Australia). The smooth muscles relaxant action of test materials was observed by administration of test drugs in a cumulative fashion directly without the use of an agonist.

To assess whether the spasmolytic activity of the test substance was through calcium channel blockade (CCB), high $\mathrm{K}^{+}(80 \mathrm{mM})$, as $\mathrm{KCl}$, was used to depolarize the preparations [15]. The $\mathrm{K}^{+}(80 \mathrm{mM})$ was added to the tissue bath, which produced a sustained contraction. The test materials were then added in a cumulative fashion to obtain concentration-dependent inhibitory responses. To confirm the $\mathrm{Ca}^{++}$antagonist property of the test substance, the tissue was allowed to stabilize in normal Tyrode's solution, which was then replaced with $\mathrm{Ca}^{++}$-free Tyrode's solution containing EDTA $(0.1 \mathrm{mM})$ for 30 minutes in order to remove $\mathrm{Ca}^{++}$from the tissues. This solution was further replaced with $\mathrm{K}^{+}$-rich and $\mathrm{Ca}^{++}$-free Tyrode's solution. Following an incubation period of $30 \mathrm{~min}$, control concentration-response curves (CRCs) of $\mathrm{Ca}^{++}$were obtained. When the control $\mathrm{Ca}^{++}$CRCs were found super-imposable (usually after two cycles), the tissue was pre-treated with the crude extract for $60 \mathrm{~min}$. The CRCs of $\mathrm{Ca}^{++}$were reconstructed in the presence of different concentrations of the extract.

\section{Rabbit and rat aortic preparations}

Rabbit and rat aorte are used commonly to study the possible vasodilator effects of test drugs. Descending thoracic aorta, isolated from either rabbits or rat were obtained and cut into $2-3-\mathrm{mm}$ wide rings that were individually mounted in $10 \mathrm{ml}$ tissue bath containing Kerb's solutions maintained at $37^{\circ} \mathrm{C}$ and aerated with carbogen gas. A resting tension of $2 \mathrm{~g}$ was applied to each tissue changes in tension were recorded through a force displacement transducer (Fort-100, WPI, Hertfordshire, UK) couple to a bridge amplifier (Transbridge 
TMB4M, WPI) and PowerLab ML845 data acquisition system (ADInstrument, Sydney, Australia). An equilibrium period of one hour was allowed before experimentation with drug as described previously [16].

Rabbit aorta was used primarily to evaluate the effect of extract on $\mathrm{K}^{+}$- and PE-induced contraction to test if the extract has effect on voltage-operated and/or receptor-operated channels and on release of calcium from intracellular stores. Rat aorta was primarily used to further evaluate if the vasodilation caused by extract was endothelial-dependent or -independent [17]. Furthermore, using different species are helpful to see the species selective effects of any extract as described previously [18].

\section{Guinea-pig atria}

Right atria isolated from guinea-pig killed by cervical dislocation were mounted in $20 \mathrm{ml}$ tissue baths containing normal Kreb's solution maintained at $32^{\circ} \mathrm{C}$ and aerated with carbogen, as described previously [19]. The tissues were allowed to beat spontaneously under the resting tension of $1 \mathrm{~g}$. Tension changes in the tissue were recorded through force-displacement transducer (model FT-03) using a grass Model 7 Polygraph. After equilibrium period of 30 minutes, control responses of isoprenaline $(1 \mu \mathrm{M})$ and acetylcholine $(1 \mu \mathrm{M})$ were obtained at least in duplicate. The test substances were then added cumulatively and the effect on force and rate of contractions was determined as percent of the pre-treated control.

\section{Acute toxicity test}

Animal were divided in groups of 5 mice each. The test was performed using increasing doses of the plant extracts $(3,5,10 \mathrm{~g} / \mathrm{kg})$, given orally, in $10 \mathrm{ml} / \mathrm{kg}$ volume to different groups serving as test groups. Another group of mice was administered saline $(10 \mathrm{ml} / \mathrm{kg}$, p.o. $)$ served as negative control. The mice were allowed food and water ad libitum during a $24 \mathrm{hr}$ test period and kept under regular observation for gross behavioural changes and mortality.

\section{Data analysis and statistics}

All the data expressed as mean \pm SEM and the median effective concentrations $\left(\mathrm{EC}_{50}\right)$ values are given as geometric mean with $95 \%$ confidence intervals (CI). CRCs were analyzed by nonlinear regression (Sigmoidal doseresponse curve variable slop). While One-way Analysis of Variance (one-way ANOVA) followed by Tukey's post-test was used to determine the significant difference in various doses, $\mathrm{P}$ value $<0.05(\mathrm{P}<0.05)$ were considered statistically significant. All the graphs, calculation and statistical analyses were performed using GraphPad Prism software version 4.00 for Windows, (GraphPad Software, San Diego California USA, http:// www.graphpad.com).

\section{Results}

\section{Phytochemical screening}

Qualitative phytochemical study that the Morinda citrifolia root extract show the presence of saponins, flavonoids, anthraquinine coumarines, sterols and phenolic compounds.

\section{Effects on rabbit jejunum}

In isolated rabbit jejunum preparation, the root extract of Morinda citrifolia (Mc.Cr), inhibited the spontaneous contractions in a concentration-dependent manner with $\mathrm{EC}_{50}$ value $(95 \% \mathrm{CI}$;) of $0.30 \mathrm{mg} / \mathrm{ml}(0.24-0.39 ; \mathrm{n}=4)$, similar to that of verapamil as shown in Figure 1. When tested against high $\mathrm{K}^{+}(80 \mathrm{mM})$-induced contractions, Mc.Cr caused relaxation with $\mathrm{EC}_{50}$ value of $0.06 \mathrm{mg} / \mathrm{ml}$ $(0.05-0.08 ; \mathrm{n}=4)$ as shown in Figure 2A. Mc.Cr caused relaxation of $\mathrm{K}^{+}(80 \mathrm{mM})$-induced contractions at lower concentration compared to that of spontaneous contractions. Similar pattern was seen with verapamil, which produced relaxation of $\mathrm{K}^{+}(80 \mathrm{mM})$-induced contractions with $\mathrm{EC}_{50}$ value of $0.04 \mu \mathrm{M} / \mathrm{ml}(0.03-0.04 ; \mathrm{n}=4)$ at lower concentration than that of spontaneous contractions in rabbit jejunum with $\mathrm{EC}_{50}$ value of $0.23 \mu \mathrm{M}$ / $\mathrm{ml}(0.19-0.27 ; \mathrm{n}=4)$ as shown in Figure 2B. Pre-treatment of the tissues with Mc.Cr $(0.03$ or $0.1 \mathrm{mg} / \mathrm{ml} ; \mathrm{n}=$ 4) showed rightward shift in the $\mathrm{Ca}^{++}$concentration response curves similar to that of verapamil as shown in Figure 3.

\section{Effect on thoracic aorta}

In endothelium-intact rat aortic preparations precontracted with phenylepherine (PE $1 \mu \mathrm{M})$, Mc.Cr caused inhibition of induced contractions dose-dependently with $\mathrm{EC}_{50}$ value of $1.23 \mathrm{mg} / \mathrm{ml}(0.98-1.55 ; \mathrm{n}=4)$. The vasorelaxant activity was not altered in the presence of L-NAME $(0.1 \mathrm{mM})$ with resulting $\mathrm{EC}_{50}$ value of 1.33 $\mathrm{mg} / \mathrm{ml}(0.88-2.01 ; \mathrm{n}=4)$ or atropine $(1.0 \mu \mathrm{M})$ with $\mathrm{EC}_{50}$ value of $1.30 \mathrm{mg} / \mathrm{ml}(0.85-1.97 ; \mathrm{n}=4)$, similarly removal of endothelium did not alter the potency. These effects were similar to those observed with verapamil as show in Figure 4.

In the rabbit aorta, Mc.Cr also caused concentrationdependent vasodilatation against $\mathrm{PE}(1 \mu \mathrm{M})$ and high $\mathrm{K}^{+}$ $(80 \mathrm{mM})$-induced contractions, with $\mathrm{EC}_{50}$ value of 1.68 $\mathrm{mg} / \mathrm{ml}(1.30-2.19 ; \mathrm{n}=4)$ and $0.76 \mathrm{mg} / \mathrm{ml}(0.69-0.84 ; \mathrm{n}=$ 4), similar to that of verapamil as shown in Figure 5. Mc.Cr was also tested in increasing doses against PE (1 $\mu \mathrm{M})$ peak responses as show in Figure 6, where it inhibited the PE $(1 \mu \mathrm{M})$ peaks in normal- $\mathrm{Ca}^{++}$and $\mathrm{Ca}^{++}$free Kerb's solution dose-dependently $(0.01-1.0 \mathrm{mg} / \mathrm{ml}, \mathrm{p}<$ $0.001 ; \mathrm{n}=4)$, similar to that of verapamil $(0.03-0.3 \mu \mathrm{M}$, $\mathrm{n}=4$ ) as shown in Figure 7.

\section{Effect on isolated guinea-pig atria}

In isolated spontaneously beating guinea-pig atrial preparations, Mc.Cr exhibited concentration-dependent 


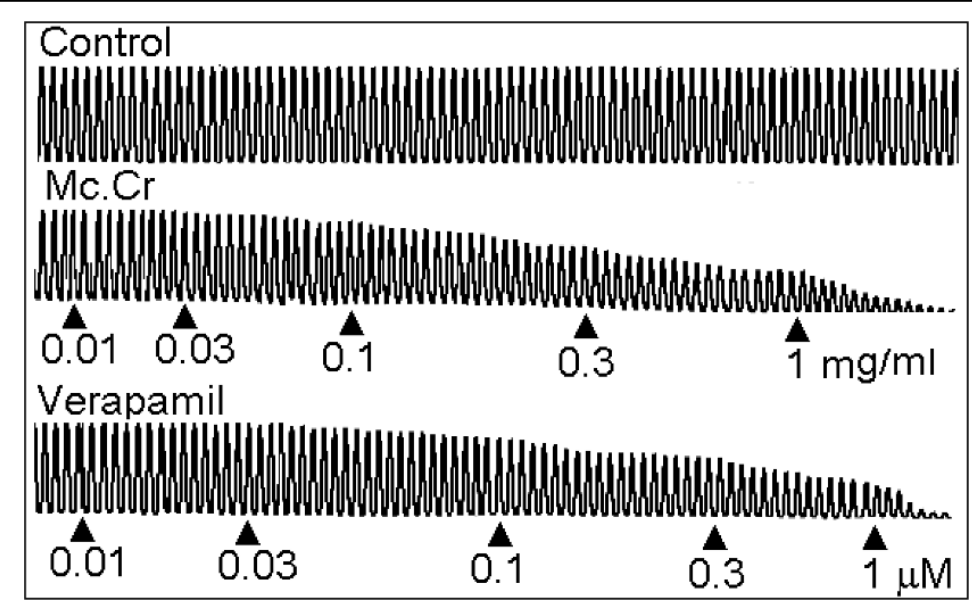

Figure 1 Typical tracing showing inhibitory effect of crude extract of Morinda citrifolia (Mc.Cr) and verapamil on the spontaneous contractions in isolated rabbit jejunum preparations.

(0.03-5.0 $\mathrm{mg} / \mathrm{ml})$ suppression of the force and rate of contractions with $\mathrm{EC}_{50}$ value of $2.52 \mathrm{mg} / \mathrm{ml}(2.01-3.15$; $\mathrm{n}=4)$ and $2.69 \mathrm{mg} / \mathrm{ml}(2.05-3.53 ; \mathrm{n}=4)$ respectively. Similar effects of verapamil were seen in this preparation as shown in Figure 8. The inhibitory effects on heart were at relatively higher concentrations than those on smooth muscle preparations $(\mathrm{P}<0.001)$.

Acute toxicity

In mice, Mc.Cr did not cause any mortality and changes in gross behaviour up to the dose of $10 \mathrm{~g} / \mathrm{Kg}$ as compared to control group.

\section{Discussion}

The $70 \%$ aqueous-ethanolic extract of the Morinda citrifolia roots (Mc.Cr) caused a concentration-dependent inhibition of spontaneous contractions in isolated rabbit jejunum preparations, thus showing antispasmodic action. In earlier studies, we observed that the spasmolytic effect of medicinal plants is usually mediated through calcium channel blockade [20,21]. To assess whether the spasmolytic activity of this plant was also mediated through $\mathrm{Ca}^{++}$channel blockade $(\mathrm{CCB})$, high $\mathrm{K}^{+}(80$ $\mathrm{mM}$ ), as $\mathrm{KCl}$, was used to depolarize the preparations
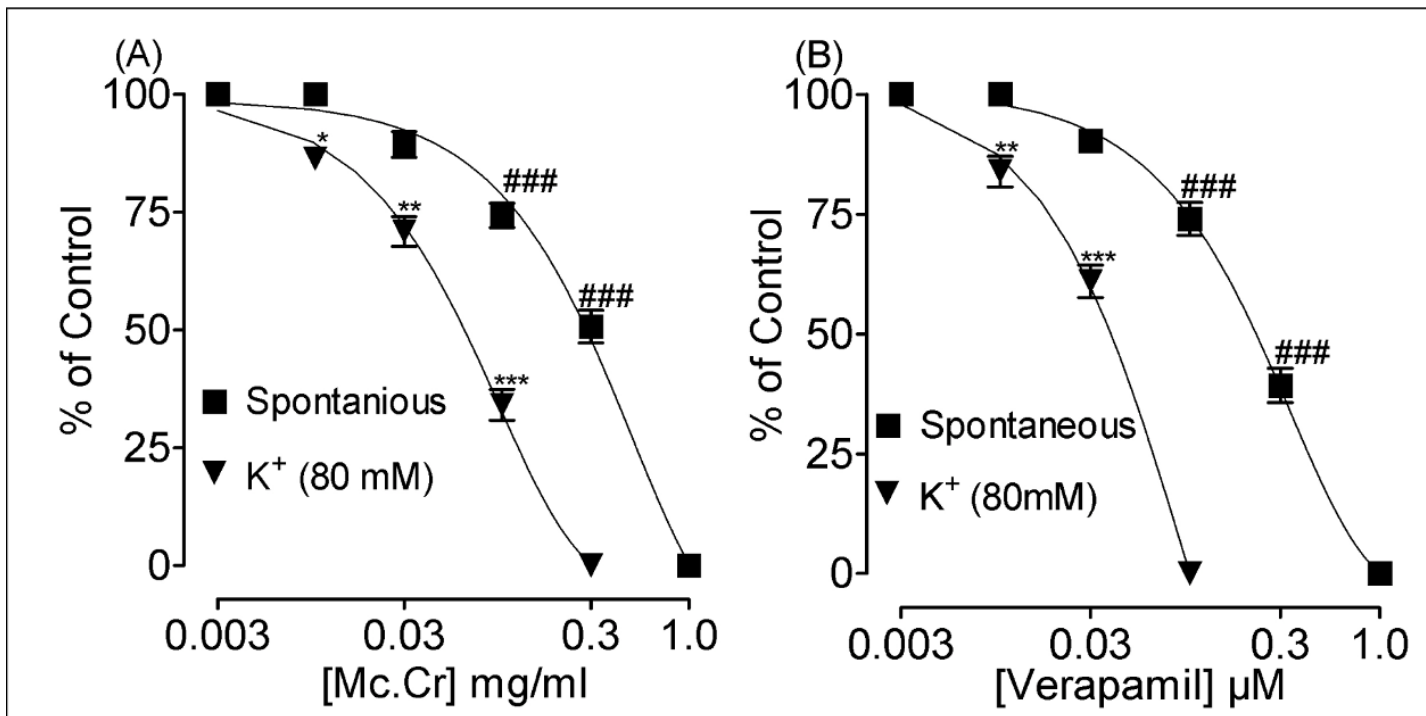

Figure 2 Inhibitory effect of the (A) Mc.Cr and (B) verapamil on spontaneous and high $\mathrm{K}^{+}$-induced contractions in isolated rabbit jejunum preparations ${ }^{\# \# \# ~} \mathrm{P}<0.001$; shows a comparison of concentration-dependent effects (specified effect compared with the effect of preceding dose) on spontaneous contractions, whereas ${ }^{*} \mathrm{P}<0.01$; ${ }^{* *} \mathrm{P}<0.001$; show comparisons of relaxant effects on $\mathrm{K}^{+}$ (80 $\mathrm{mM})$-induced contractions. 


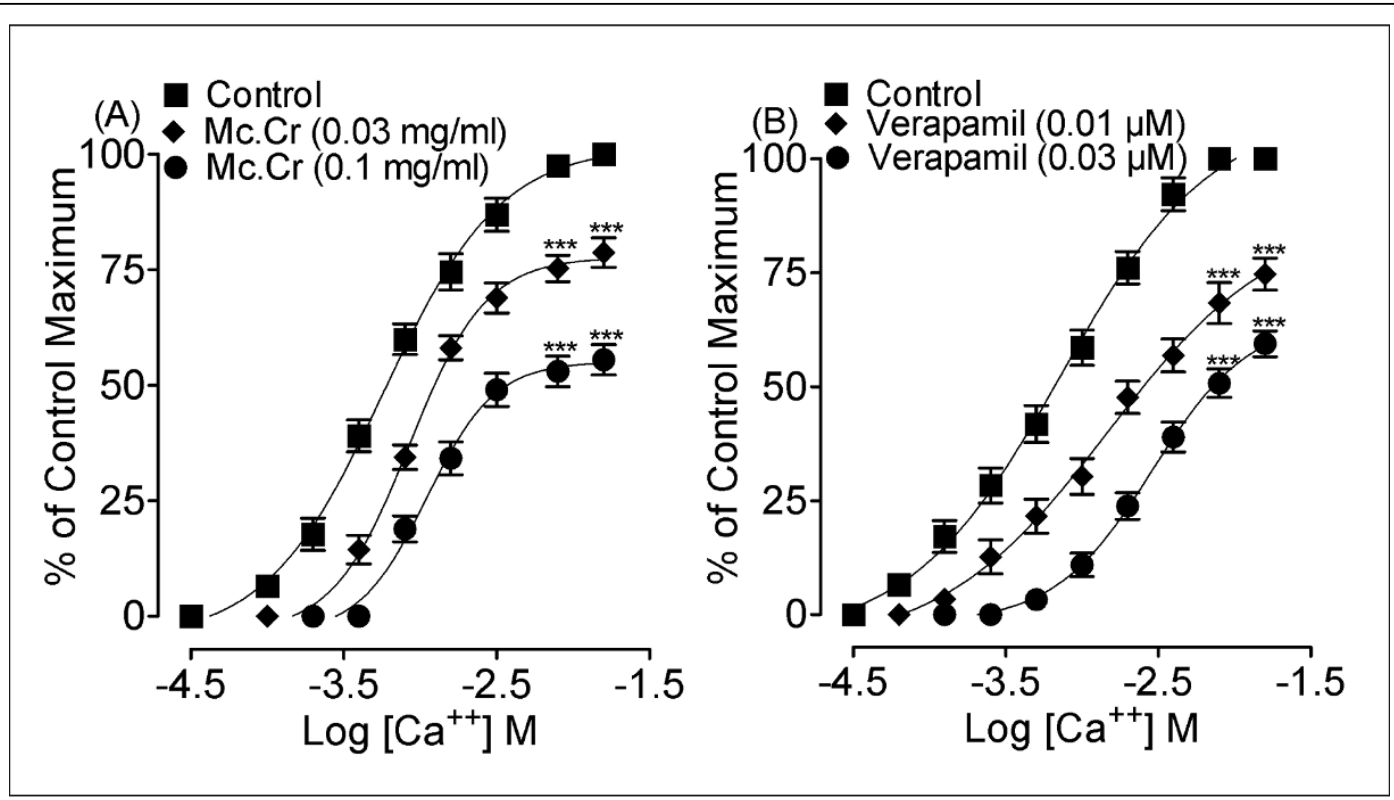

Figure 3 Concentration-response curves of $\mathrm{Ca}^{++}$in the absence and presence of the increasing concentrations of $\mathrm{Mc} . \mathrm{Cr}(\mathrm{A})$ and verapamil (B), constructed in $\mathrm{Ca}^{++}$-free and $\mathrm{K}^{+}$-rich $(80 \mathrm{mM})$ Tyrode's solution in isolated rabbit jejunum. ${ }^{* * *}<0.001$; compared to the respective control.

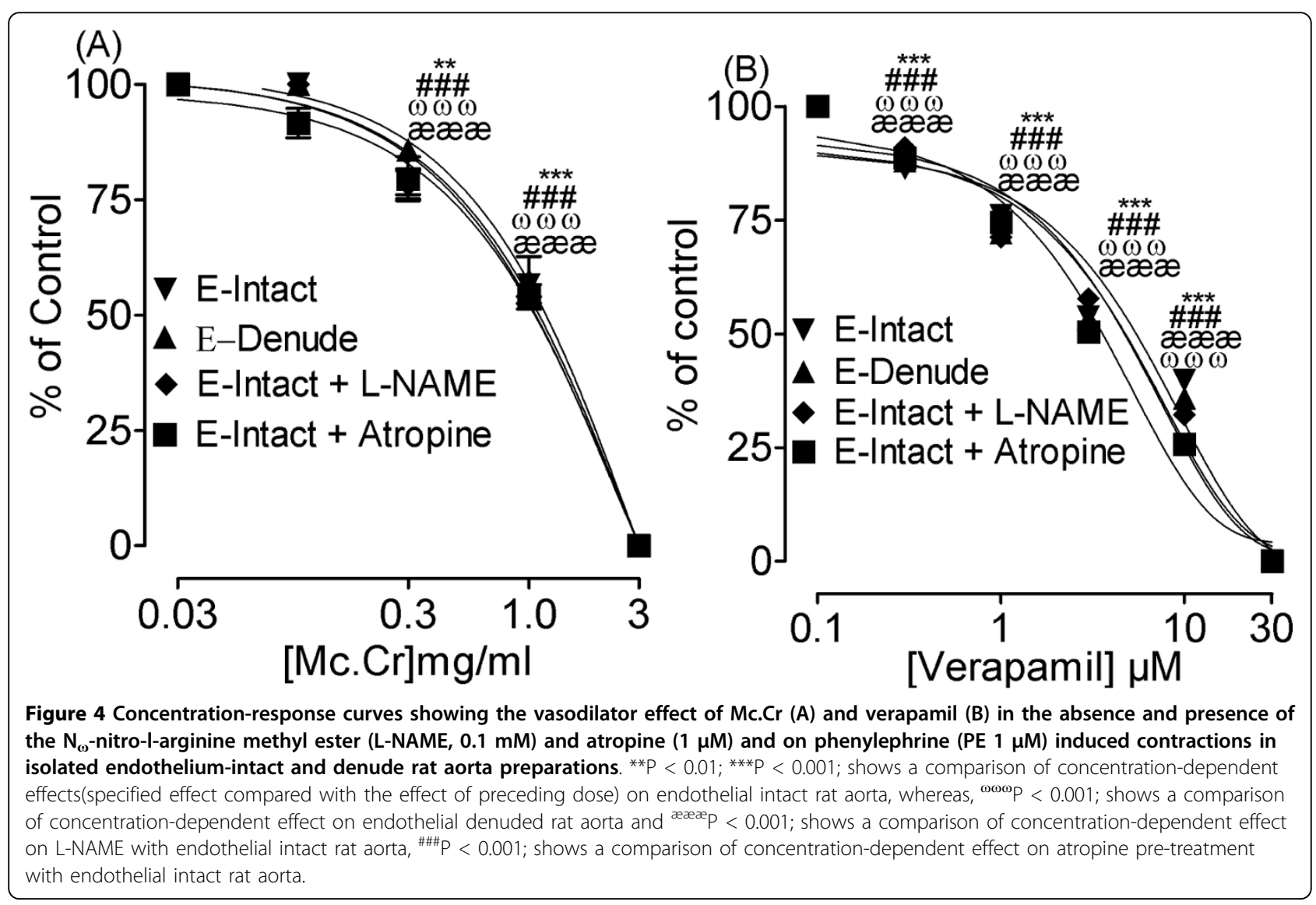




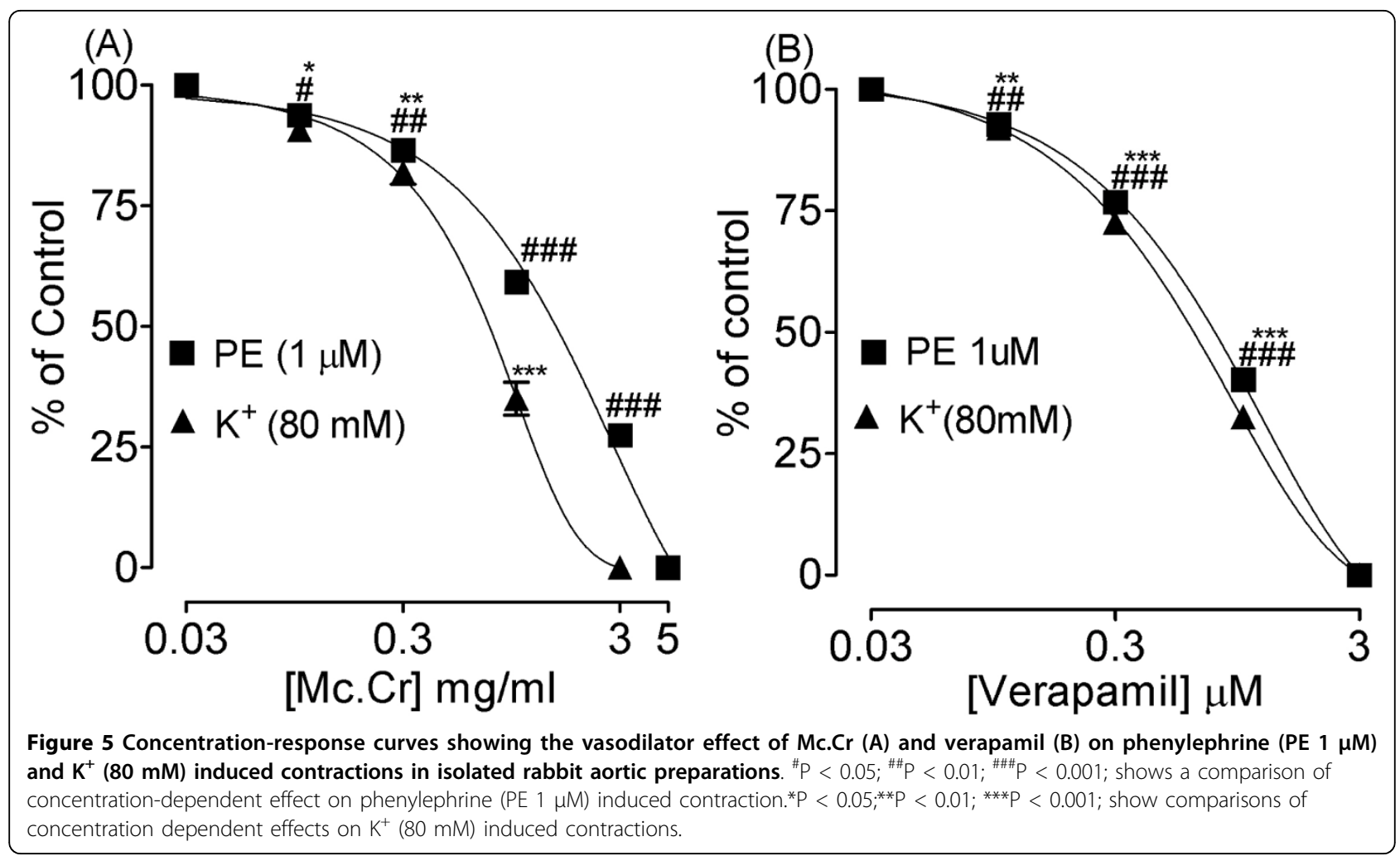

[15]. High $\mathrm{K}^{+}$(> $30 \mathrm{mM}$ ) is known to cause smooth muscle contractions through opening of voltage-dependent L-type $\mathrm{Ca}^{++}$channels, thus allowing influx of extracellular $\mathrm{Ca}^{++}$causing a contractile effect [22] and a substance causing inhibition of high $\mathrm{K}^{+}$-induced contraction is considered as a blocker of $\mathrm{Ca}^{++}$influx [23]. $\mathrm{Mc}$. Cr relaxed the high $\mathrm{K}^{+}(80 \mathrm{mM})$-induced contractions, similar to that caused by verapamil, a standard $\mathrm{Ca}$ ${ }^{++}$antagonist [24]. The presence of $\mathrm{Ca}^{++}$antagonist constituent(s) was further confirmed when pre-treatment of the tissue with Mc.Cr shifted the $\mathrm{Ca}^{++} \mathrm{CRCs}$ to the right. Calcium antagonists form an important therapeutic group and the common characteristic of these drugs are their dose-dependent inhibition of slow entry of $\mathrm{Ca}^{+}$ ${ }^{+}$and their capacity for reversal of this effect by $\mathrm{Ca}^{++}$ [24]. The spasmolytic activity of Mc.Cr mediated possibly through $\mathrm{Ca}^{++}$antagonist effect explains its therapeutic usefulness in hyperactive gut disorders, such as abdominal colic and diarrhoea, as the CCB are known to be useful in such disorders [25].

Blood pressure is the product of cardiac output and peripheral resistance, increase in either or both can contribute to the development of hypertension. Since Morinda citrifolia is used in hypertension, the plant extract was studied further for its possible mode of action in isolated cardiovascular preparations. In guinea-pig right atria, Mc.Cr caused suppression of the force and rate of spontaneous contractions in a concentration-dependent manner, similar to that caused by verapamil. In rat and rabbit aortae, Mc.Cr also caused relaxation of contractions induced by either PE or high $\mathrm{K}^{+}$, similar to that of verapamil. In order to investigate if $\mathrm{Mc}$. Cr also affects intracellular stores, $\mathrm{Mc}$.Cr was tested against PE-induced contractions in $\mathrm{Ca}^{++}$-free solution, where it caused concentration-dependent suppression of contractile responses of $\mathrm{PE}$, similar to those observed with verapamil, indicating that the extract is inhibiting the release of calcium from intracellular stores [17]. To investigate involvement of other mechanisms, the rat aorta was used. In this preparation, the vasodilatory response was not altered by removal of endothelium and in the presence of either atropine (a standard muscarinic antagonist) [26] or L-NAME (a standard nitric oxide synthase inhibitor) [27]. These finding suggest that the vasodilatory response of $\mathrm{Mc}$. Cr is mediated through inhibition of receptor and voltage operated calcium channels and inhibition of release of calcium from intracellular stores. However, release of vasoactive substances from endothelium, or nitric oxide synthase or stimulation muscaric receptors do not appear to play role in the vasodilaroy activity of Mc.Cr.

Furthermore, the CCB effects of Mc.Cr in the gut or vascular tissues were observed at lower concentrations than the effect in cardiac tissue, which indicates selective effect of this plant in smooth muscle preparations. This difference may be due to the heterogeneity of 


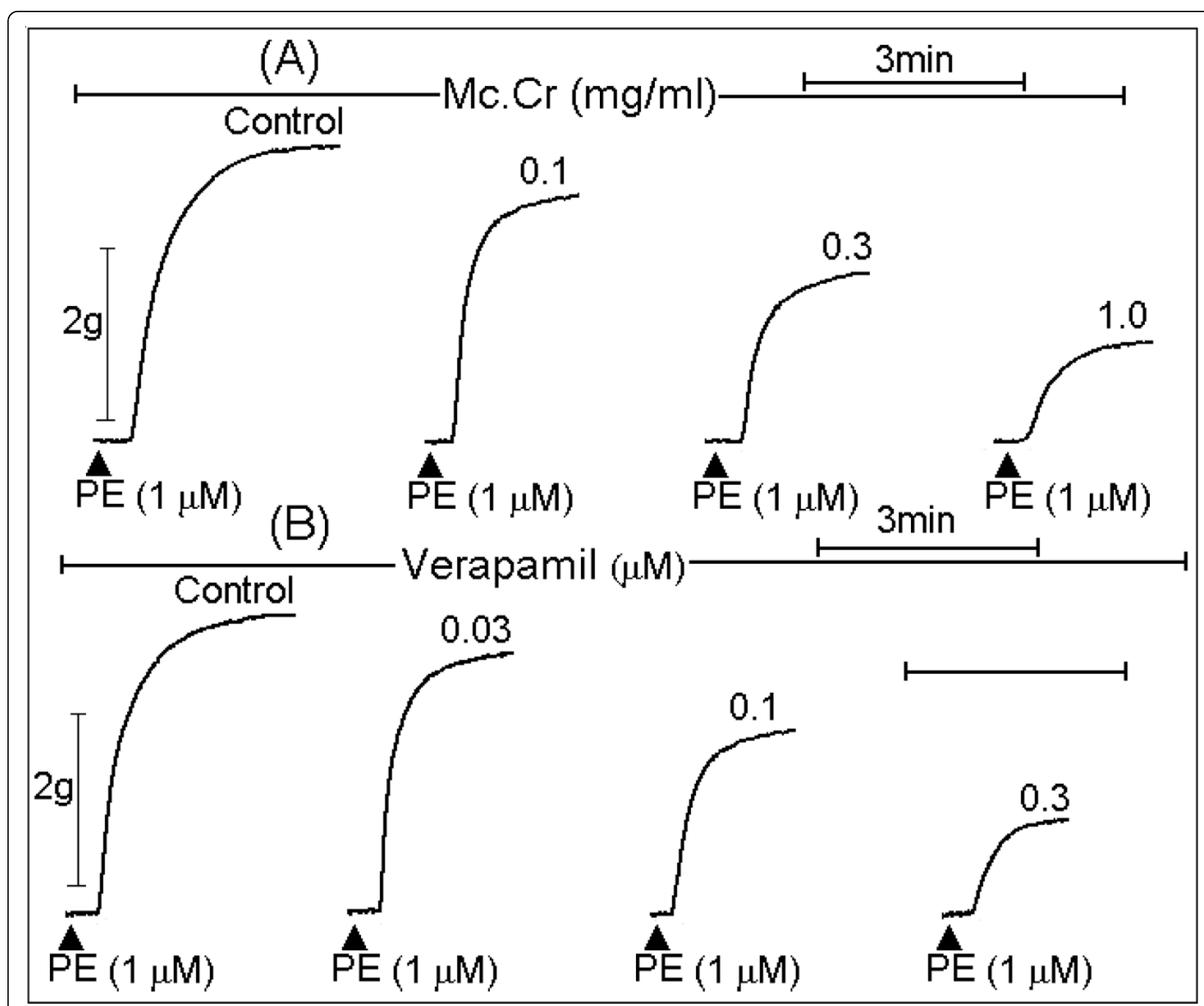

Figure 6 Typical tracing showing the increasing concentration-dependent suppression of (A) Mc.Cr and (B) verapamil on control phenylephrine (PE $1 \mu \mathrm{M})$ peaks in the normal- $\mathrm{Ca}^{++}$and $\mathrm{Ca}^{++}$-free Kerb's solution.

calcium channels in different tissues, as different CCBs exhibit selectivity for a specific organ system [28]. Therefore, studies at molecular and cellular level are suggested to evaluate exact mechanism of action(s).

In acute toxicity studies Mc.Cr did not cause any mortality upto $10 \mathrm{~g} / \mathrm{Kg}$ dose, which is much higher than the routinely used dose. However, more detailed subacute and chronic toxicity studies are required to establish the safety of this commonly used plant.

\section{Conclusions}

In summary, the findings suggest that Mc.Cr has antispasmodic, vasodilator and cardiodepressant activities which are mediated possibly through blockade of calcium channels as well as release of calcium from intracellular stores. These findings may explain the medicinal use of Morinda citrifolia in abdominal colic, diarrhoea and hypertension. However, more detailed studies are required to establish the safety, efficacy and active constituents of this plant.

\section{Acknowledgements}

This study was supported by the Pakistan Science Foundation through research project \# PSF/Res/S-AKU/BIO (377).

We also appreciate the supply of Morinda citrifolia extract as a gift from a M/ S Sami Labs Limited 19/1, 19/2, 1st Main II Phase, Peenya, Peenya Industrial Area Bangalor-560 058, India.

We are thankful to Malik Hassan Mehmood for his technical guide and support.

\section{Author details}

${ }^{1}$ Natural Product Research Division, Department of Biological and Biomedical Sciences, Aga Khan University Medical College, stadium road, Karachi-74800, Pakistan. ${ }^{2}$ Departments of Pharmacy and Biochemistry, University of Balochistan, Sariab road, Quetta, Pakistan. ${ }^{3}$ King Saud University, Riyadh, Kingdom of Saudi Arabia. 


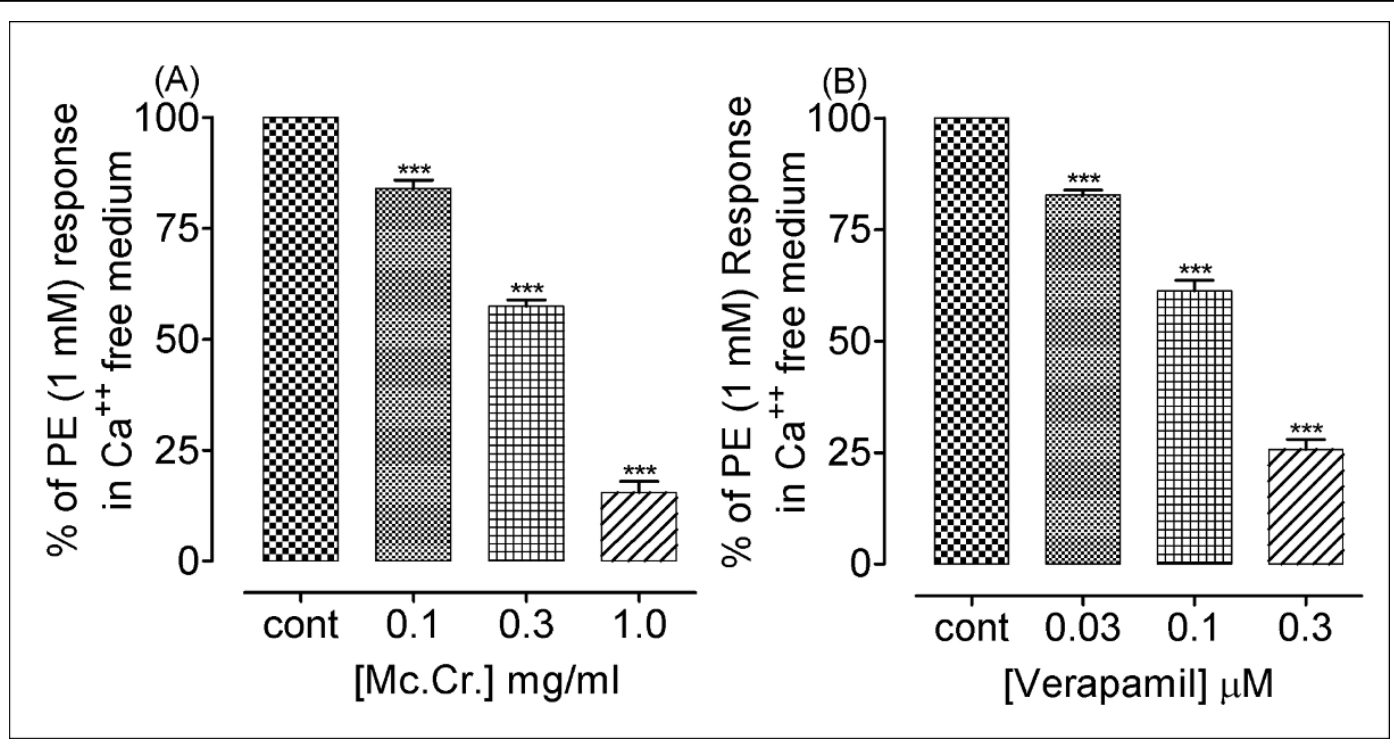

Figure 7 Bar chart showing the inhibitory effects of (A) Mc.Cr and (B) verapamil on PE responses in $\mathrm{Ca}^{++}$-free $\mathrm{Krebs}$ solution in isolated rabbit aorta preparations. ${ }^{* *} \mathrm{P}<0.001$; shows a comparison of dose dependent effect on phenylephrine (PE $\left.1 \mu \mathrm{M}\right)$ rabbit aorta.

Authors' contributions

AHG identified the plant, raised funds, supervised the work and refined the manuscript for publication. SRM carried out the draft, experimental work, data collection and evaluation, literature search and manuscript preparation. $\mathrm{J}$ and MY co-supervised the work and corrected the manuscript for publication. NA helped in study design, analysis of data and preparing draft manuscript. AK and NR helped in the experimental work, analysis of data and preparing draft manuscript. All authors read and approved the final manuscript for publication.

\section{Competing interests}

The authors declare that they have no competing interests.

Received: 11 June 2009

Accepted: 13 January 2010 Published: 13 January 2010

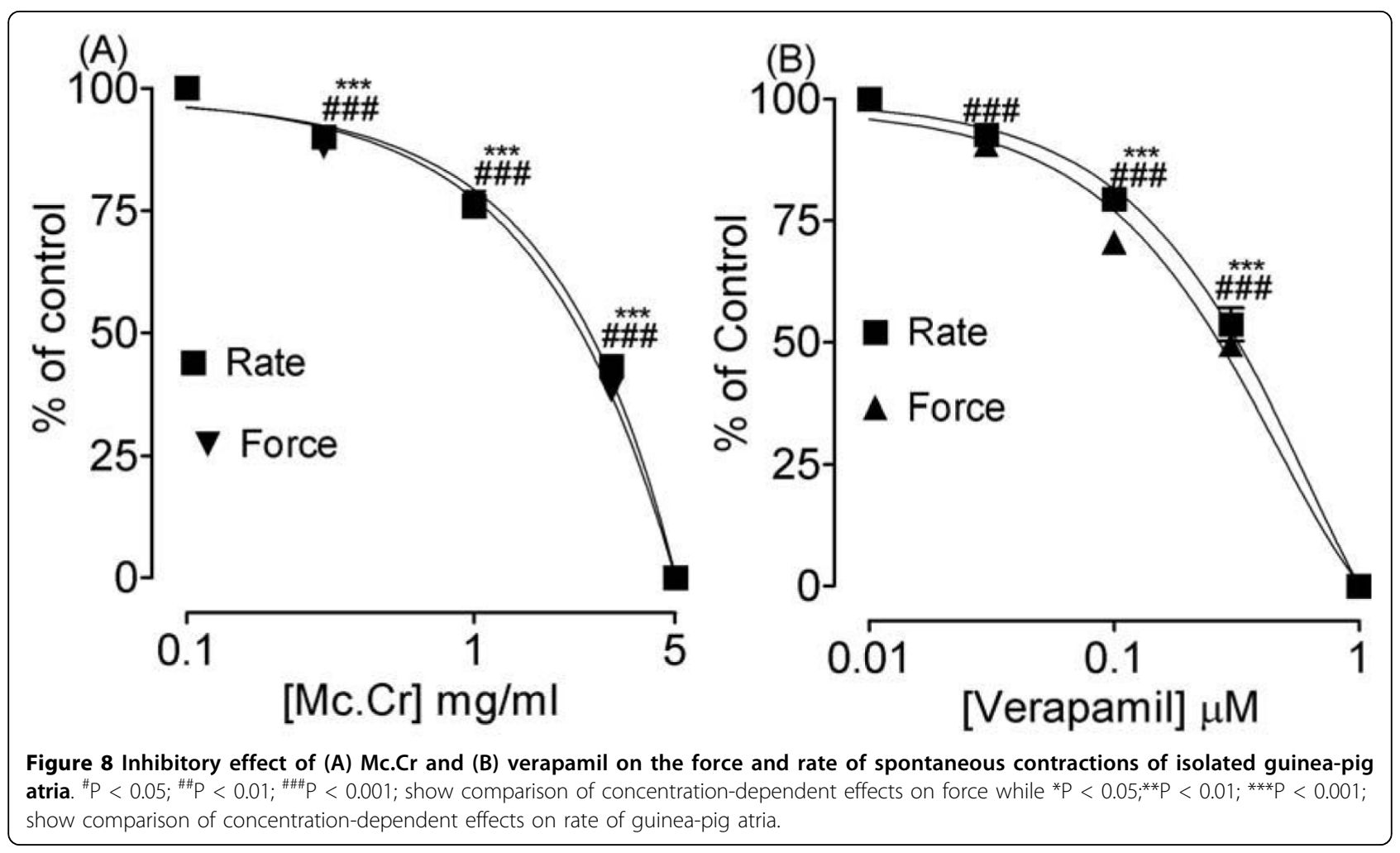




\section{References}

1. Potterat O, Hamburger M: Morinda citrifolia (Noni) Fruit - Phytochemistry, Pharmacology, Safety Institute of Pharmaceutical Biology. Planta Medica 2007, 73:191-199.

2. Wang MY, West BJ, Jensen CJ, Nowicki D, Chen SU, Palu AK, Anderson G: Morinda citrifolia (Noni) A literature review and recent advances in Noni research. Acta Pharmacologica Sinica 2002, 23(1 2):1127-1141.

3. Hirazumi A, Furusawa E: An immunomodulatory polysaccharide-rich substance from the fruit juice of Morinda citrifolia (Noni) with antitumor activity. Phytotherapy Research 1999, 13:380-7.

4. The history of Noni. http://altmed.creighton.edu/noni/history.htm

5. Dixon AR, McMillan H, Etkin NL: The transformation of Noni, a traditional Polynesian medicine (Morinda citrifolia, Rubiaceae). Economic botany 1999, 53:51-68.

6. Ayanblu F, Wang MY, Peng L, Nowicki J, Anderson G, Nowiciki D: Antithrombotic effect of Morinda citrifolia (Noni) fruit juice on the jugular vein thrombosis induced by ferric chloride in male adult SD rats. Arteriosclerosis Thrombosis and Vascular Biology 2006, 26:E104.

7. Zin ZM, Abdul-Hamid A, Osman A: Antioxidative activity of extracts from Menkudu (Morinda citrifolia) root, fruit and leaf. Food Chemistry 2002, 78:227-3.

8. Basar S, Uhlenhut K, Hogger P, Schone F, Westendorf J: Analgesic and antiinflammatory activity of Morinda citrifolia L. (Noni) fruit. Phytotherapy Research 2010, 24(1):38-42.

9. Palu A, Deng S, West B, Jensen J: Xanthine oxidase inhibiting effects of noni (Morinda citrifolia) fruit juice. Phytotherapy Research 2009, 23(12):1790-1.

10. Dang-Van-Ho : Treatment and prevention of hypertension and its cerebral complications by total root extracts of Morinda citrifolia. Press Med 2 1955, 63(72):1478, French.

11. Runnie I, Salleh MN, Mohamed S, Head RJ, Abeywardena MY: Vasorelaxation induced by common edible tropical plant extracts in isolated rat aorta and mesenteric vascular bed. Journal of Ethnopharmacology 2004, 92:311-316.

12. Khan A, Gilani AH: Pharmacodynamic evaluation of Terminalia Bellerica for its antihypertensive effects. Journal of food and drug analysis 2008, 16:3.

13. National Research Council: Guide for the Care and Use of Laboratory. Animal Washington: National Academy Press 1996.

14. Gilani AH, Shah AJ, Ghayur MN, Majeed K: Pharmacological basis for the use of turmeric in gastrointestinal and respiratory disorders. Life Sciences 2005, 76:3089-3105.

15. Farre AJ, Columbo M, Fort M, Gutierrez B: Differential effects of various Ca ${ }^{++}$antagonists. General Pharmacology 1991, 22:177-181.

16. Gilani $A H$, Jabeen $Q$, Ghayur MN, Janbaz KH, Akhtar MS: Studies on the antihypertensive, antispasmodic, bronchodilator and hepatoprotective activities of the Carum copticum seed extract. Journal of Ethnopharmacology 2005, 98:127-135.

17. Ghayur MN, Gilani AH: Ginger lowers blood pressure through blockade of voltage-dependent calcium channels. Cardiovascular Pharmacology 2005, 45:74-80.

18. Ghayur MN, Gilani AH, Houghton PJ: Species differences in the gut stimulatory effects of radish seeds. Journal of Pharmacy and Pharmacology 2005, 57:1-9.

19. Konan AB, Datte JY, Yapo PA: Nitric oxide pathway-mediated relaxant effect of aqueous sesame leaves extract (Sesamum radiatum Schum. \& Thonn.) in the guinea-pig isolated aorta smooth muscle. BMC Complementary and Alternative Medicine 2008, 8:23.

20. Gilani AH, Aziz N, Khan MA, Shaheen F, Jabeen Q, Siddiqui BS, Herzig JW: Ethnopharmacological evaluation of the anticonvulsant, sedative and antispasmodic activities of Lavandula stoechas. Journal of Ethnopharmacology 2000, 71:161-67.

21. Gilani $\mathrm{AH}$, Khan $\mathrm{A}$, Ghayur $\mathrm{MN}: \mathrm{Ca}^{2+}$ antagonist and cholinergic activities explain the medicinal use of olive in gut disorders. Nutrition Research 2006, 26:277-283.

22. Bolton TB: Mechanism of action of transmitters and other substances on smooth muscles. Physiological Review 1979, 59:606-718.

23. Godfraind T, Miller R, Wibo M: Calcium antagonism and calcium entry blockade. Pharmacological Reviews 1986, 38:321-416.
24. Fleckenstein A: Specific pharmacology of $\mathrm{Ca}^{++}$in myocardium cardiac pacemakers and vascular smooth muscle. Reviews of Pharmacology and Toxicology 1977, 17:149-166.

25. Pasricha PJ: Treatment of disorders of bowel motility and water flux: antimemetics; agents used in biliary and pancreatic disease. Goodman and Gilman's the Pharmacological Basis of Therapeutics New York: McGrawHillBrunton LL, Lazo JS, Parker KL, Gilman's AG, 11 2006, 983-1008.

26. Furchgott RF, Zawadski JV: The obligatory role of endothelium cell in the relaxation of arterial smooth muscle by acetylcholine. Nature 1980, 299:373-376

27. Thorin E, Hunang PL, Fishmsn MC, Bevan JA: Nitric oxide inhibition alpha2 adrenoceptor-mediated endothelium-dependent vasodilation. Circulation Research 1998, 82:1323-1329.

28. Vanhoutte PM: Differential effect of calcium entry block on vascular smooth muscle. American Physiological Society New perspective on calcium antagonist BethesdaWeis GB 1990, 1981:109-121.

\section{Pre-publication history}

The pre-publication history for this paper can be accessed here:http://www biomedcentral.com/1472-6882/10/2/prepub

doi:10.1186/1472-6882-10-2

Cite this article as: Gilani et al: Antispasmodic and vasodilator activities of Morinda citrifolia root extract are mediated through blockade of voltage dependent calcium channels. BMC Complementary and Alternative Medicine 2010 10:2

\section{Submit your next manuscript to BioMed Central and take full advantage of:}

- Convenient online submission

- Thorough peer review

- No space constraints or color figure charges

- Immediate publication on acceptance

- Inclusion in PubMed, CAS, Scopus and Google Scholar

- Research which is freely available for redistribution

Submit your manuscript at www.biomedcentral.com/submit
C Biomed Central 